\title{
Restricting pesticides on a traditional crop: the example of khat (Catha edulis) and the Njuri Ncheke of Meru, Kenya
}

\author{
James S. Krueger ${ }^{1}$ and Daniel M. Mutyambai ${ }^{2,3}$
}

\begin{abstract}
Rampant increase and diversification of synthetic pesticides poses health, environmental, and livelihood risks especially to smallholder farmers who dominate agriculture in sub-Saharan Africa. Legal mechanisms for regulating pesticides, although important, have not fully addressed the dangers of ecological services disruptions due to accumulation of different pesticides over time. Legal mechanisms also are not well suited to developing countries because of weak monitoring and enforcement capacity. Understanding the role of other accountability mechanisms in farming, driven by norm leaders in the community, is thus of paramount importance. We investigated the effectiveness of a traditional accountability mechanism, i.e., local councils of elders known as the Njuri Ncheke, in controlling pesticide use in khat (Catha edulis). Khat samples were taken from traditional production systems in which these councils have influence and from commercial production systems lacking the councils' influence. The samples were analyzed for pesticide residues using liquid chromatography mass spectrometry. Individual farmer interviews were also carried out, inquiring about the influence of the Njuri Ncheke on the local community and on pesticide use in crop production. Our results show that a variety of agrochemical pesticides are being used by smallholder khat farmers and that local Njuri Ncheke councils have had success in limiting pesticide use, arguably more success than any government agency working to control pesticides on any local crop. These results show the potential of public accountability through traditional institutions like councils of elders and the role they can play in complimenting legal regulation mechanisms for successful pesticides management in agroecosytems.
\end{abstract}

Key Words: agricultural law; agroecosystems; Kenya; khat; legal pluralism; pesticides

\section{INTRODUCTION}

Farmers around the world are getting greater access to synthetic pesticides. This includes not only large-scale commercial growers but also smallholder farmers who dominate agriculture in regions like sub-Saharan Africa (Adjognon et al. 2017, Sheahan and Barrett 2017, Ottiger et al. 2020). Even traditional growers using agroecological techniques, like Kenyan khat (Catha edulis) farmers, are applying a variety of new pesticide products available at local agrochemical stores.

The pattern of increased and diversified use of agrochemicals by such a wide variety of actors raises questions about how these chemicals can be controlled. Environmentalists and others have set off alarm bells about the potentially catastrophic impacts of agrochemical overuse, for example that it is precipitating an "insect apocalypse" (Goulson 2019) and contributing to a wave of cancer and child development disorders (Marquez and Schafer 2016, Nicolopoulou-Stamati et al. 2016). Legal mechanisms such as verifying each pesticide's safety and prohibiting those pesticides found to be unsafe, although important, have not addressed bigger picture concerns about the total amount of pesticide being applied, its geographic distribution, its cumulative effects over time when mixed in the environment with other pesticides, and the danger of fundamental disruptions in ecology (Lydy et al. 2004, Knudsen 2017, Hendriks et al. 2019, Silva et al. 2019). Moreover, such legal mechanisms are not well-suited to developing countries that have weak monitoring and enforcement capacity and many small-scale farmers (Jansen 2007).

In Kenya, for example, the average citizen has almost no information about what mix of agrochemicals is present in local foods, let alone in the ambient environment. Agrochemical regulation in Kenya, for example controlling pesticide residue in foods, is directed almost entirely at crops being exported to Europe rather than at domestic crops eaten by Kenyans. Potential negative health and environmental impacts of pesticides are compounded in the African context because of the large percentage of people who are engaged in rural farming and who are exposed to pesticides on farm (with women of child-bearing age being particularly vulnerable to harm), lack of proper safety equipment and training for farmers and sprayers, excessive pesticide dosage and frequency of application, failure to wait the requisite period after spraying and before harvesting, and informal markets in pesticides (and lack of safety labeling or lack of labeling that farmers can easily understand; Ngowi et al. 2007, de Bon et al. 2014, Mengistie et al. 2017).

If the model of imposing expert rules, both state agricultural laws and private standards like USDA organic and GlobalGAP, is too expensive or not workable on its own, particularly for developing countries, there is an obvious need to think about additional accountability mechanisms and the state framework for facilitating them. This line of reasoning is not well-explored in the literature, in part because it traverses competing disciplines and ideological orientations, like law, sociology, and agricultural and environmental sciences. Our approach is interdisciplinary, using a legal notion of accountability, a sociological and anthropological sensitivity to real-life behavior, and natural science testing for pesticides.

We inquire about whether a traditional accountability mechanism, driven by norm-leaders in the community, can be effective at controlling agrochemical use on a traditional crop. The context is smallholder khat agriculture in Igembe in Meru

${ }^{1}$ Mekelle University School of Law, ${ }^{2}$ International Centre of Insect Physiology and Ecology (ICIPE), ${ }^{3}$ Department of Life Sciences, South Eastern Kenya University (SEKU) 
County, Kenya. Because khat was until recently ignored by agricultural officials, local Njuri Ncheke councils of elders have played a significant role in managing it.

Our hypothesis is that khat that is grown in places of traditional production will have fewer pesticide residues than khat grown in places of more commercial production, and that this can be attributed in part to Njuri Ncheke influence. We test this hypothesis by taking khat samples from randomly selected farms in locations of commercial and traditional khat production in Igembe and analyzing them for a range of pesticide residues. These results are then correlated with results from background interviews and surveys of farmers asking about the extent of Njuri Ncheke influence in the local community and about local pest problems and pesticides practices on a variety of crops.

The analysis shows both that a wide variety of potentially harmful pesticides are being used by smallholders on this traditional crop, and that local Njuri Ncheke councils, despite their lack of scientific knowledge about pesticides and lack of any formal mandate from Kenyan government agencies, have had some success in limiting pesticide use, arguably more success than any government agency working to control pesticides on any local crop. This is highly significant, not least because the Njuri Ncheke performs its work at very low cost, whereas Kenyan agencies (and also private farm certification programs) have very high monitoring and enforcement costs.

\section{BACKGROUND}

\section{Study site}

Igembe, $0^{\circ} 13^{\prime} 44.04^{\prime \prime} \mathrm{N}, 37^{\circ} 55^{\prime} 31.80^{\prime \prime} \mathrm{E}$, is a region in Meru County, Kenya, where khat has been grown for generations according to local agricultural practices. In 2019, Igembe had approximately 552,375 people, or 285 people per square kilometer (KNBS 2019). One of the most significant economic trends over time has been rising population density, shrinking smallholder plot sizes, and, by necessity, more intensified farming. Whereas khat was once one traditional crop among many, it has become the dominant crop in Igembe owing to its commercial success in national and export markets.

Khat, known locally in Kenya as miraa or muguka, is a tree/shrub crop. Its shoots and leaves are chewed fresh for their mild stimulating effect. In Igembe, khat is farmed and chewed mainly by men, a practice based in tradition that continues more-or-less into the present. Igembe farmers have a unique way of cultivating khat trees that maximizes shoot growth. They shape leafy branches downward and keep the upper part of the tree bare except for new shoots. The skeletal upper canopy then allows sunlight to reach through for understory crops (Fig. 1). In other places where khat is grown, like Ethiopia and Yemen as well as Mbeere in Kenya, the crop is kept to a small bush size and monocropped in rows, in comparison to Igembe where khat is grown into a tree and intercropped with understory crops.

Igembe people have a long tradition of innovation in agroforestry and in applying diverse cropping strategies across Igembe's many microclimates. Generally, for midelevation, rainfed agriculture, there are two growing seasons per year corresponding to the two rainy seasons: a shorter one from March to May and a longer one from mid-October to November (Ishida 2007:44). A common farming strategy in the past was to plant agroforestry trees and tubers around the homestead in midelevation zones. For example, farmers grew yam vines up and around mwenjela trees (Cussonia holstii) and fed tree clippings to goats. Igembe farmers living in midelevation zones also had access to hotter lower-elevation lands where they seasonally grew field crops like millet and pulses (Bernard 1972). Nowadays, one can find a variety of crops on khat farms: maize, black beans, potato, false banana (which provides leaves for wrapping khat), cassava, sweet potato, collard, arrowroot, millet, sorghum, amaranth, cow peas, green gram, pumpkin, coffee, sugarcane, tea, and a variety of vegetables like onion, carrot, and tomato, among others. Fruit trees like banana, guava, mango, papaya, avocado, and orange are also found on khat farms in Igembe.

Fig. 1. Khat (Catha edulis) tree with shoots.

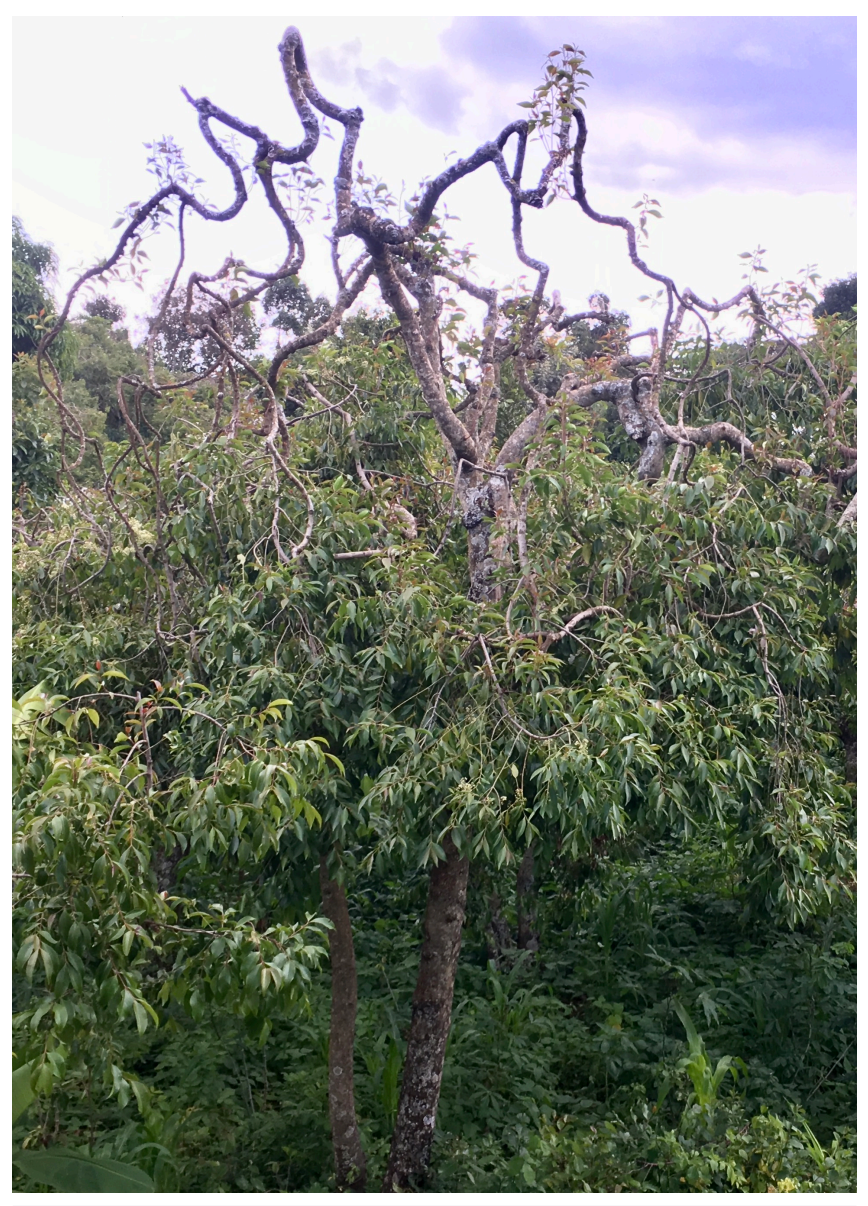

In Kenya, khat is affected by several pests and diseases (see https:// www.greenlife.co.ke/overcome-miraa-challenges-this-season/). Major khat diseases are powdery mildew, blight, and leaf spots. Below ground pests include chafer grubs, nematodes, and moles, which destroy the rooting system of the crop making water and nutrient uptake impossible and leading to wilting and drying up. Above ground, there are stem borers, which burrow holes in the stems and weaken and break the plant. Sucking pests include thrips, red spider mites, scales, and antestia bugs, which suck nutrients and enriched sap from the stems and leaves resulting in unevenly folded 
leaves, which have low market value. Several biting and chewing insects affect khat including caterpillars and occasional locust swarms. These biting insects chew off leaves reducing surface area for photosynthesis and consequently the quality of the khat twigs. There has been an upsurge of khat pests recently including scales and locusts causing huge losses to farmers. To counter these pests and diseases on khat and other crops, farmers often resort to pesticides.

\section{Njuri Ncheke}

The Njuri Ncheke is regarded as the traditional government of the Meru people. It has deliberative councils that meet at local and regional levels to issue orders and resolve disputes. Membership in the Njuri Ncheke is open to all adult Meru men but requires an initial financial contribution and on-going commitment to exhibiting good behavior and protecting Njuri Ncheke secrets. When asked about the criteria for joining the Njuri, elders in Igembe listed several moral qualities such as straight dealing, honesty, generosity, good work ethic, and calm temperament.

Local Njuri Ncheke councils in Igembe have been active in settling a variety of disputes, such as land boundary disputes, inheritance disputes, family matters like marital disputes and child welfare, and small-scale crimes and misdeeds like theft. The Njuri is most well-known among local farmers in Igembe for its ability to compel people to tell the truth by administering powerful ritual oaths. The Njuri is not involved in regulating other crops but claim a special role in managing khat because it is Igembe's unique traditional crop. In addition, the pan-Meru Njuri council has explicitly embraced an environmental mission as part of its duty to look out for the interests of future generations of Meru.

The Kenyan government has some ambivalence about working with the Njuri, even though the Njuri is now widely accepted as a legitimate forum for alternative dispute resolution. The British colonial government initially outlawed the Njuri as a witchcraft organization in the 1920s. Subsequently in the 1930s and 40s through a series of sympathetic district commissioners, the colonial government came to rely on the Njuri, particularly the pan-Meru Njuri Ncheke council that meets at Nchiru, to implement government policy, particularly things like health policy, e.g., ending female circumcision and improving sanitation, and land policy, e.g., controlling soil erosion and managing the transition to individual land ownership (Fadiman 1993, Thomas 2003, Krueger and Jacobs 2016). During Kenyan independence, the Njuri sought greater local autonomy to govern in Meru, but this effort ultimately was rejected by Kenyan nationalists and the first President, Jomo Kenyatta, who insisted that Kenya could have only one government. Nonetheless, local Njuri Ncheke councils rose to prominence as a legitimate forum for resolving local property disputes during the postindependence transition from customary property to formal private property.

The Njuri's regulatory techniques are complex and indirect and draw from Meru spiritual beliefs. Traditionally, they worked with and through other Igembe social institutions like clans and age sets. Their present approach to regulation is akin to restorative justice. They help to generate consensus around wrong behaviors, hold meetings in which they identify individual wrongdoers and categories of wrongdoers, and then use curses and rituals (and, rarely, direct action) to threaten, cajole, and punish wrongdoers.
A curse, for example, puts a person into a state of ritual uncleanliness, which if not remedied prompts misfortunes like illness or accident, not only to the cursed person but also to those people surrounding him or her. A curse thus causes a person to be shunned by others in the community and puts tremendous social pressure on the person to admit wrongdoing, seek ritual expiation of the curse, and come clean (Fadiman 1977).

\section{Traditional versus commercial khat producing areas}

Of key importance to the study is the distinction between traditional and commercial areas of khat cultivation (see Fig. 2 and Fig. 3). For our purposes, the traditional areas of cultivation are distinguished by having greater Njuri influence. This is supported by interviews with farmers.

The distinction between "traditional" and "commercial" khat cultivation is also made by the farmers themselves. In addition to greater Njuri influence, some factors that farmers use to describe

Fig. 2. Traditional khat (Catha edulis) farm with intercropping.

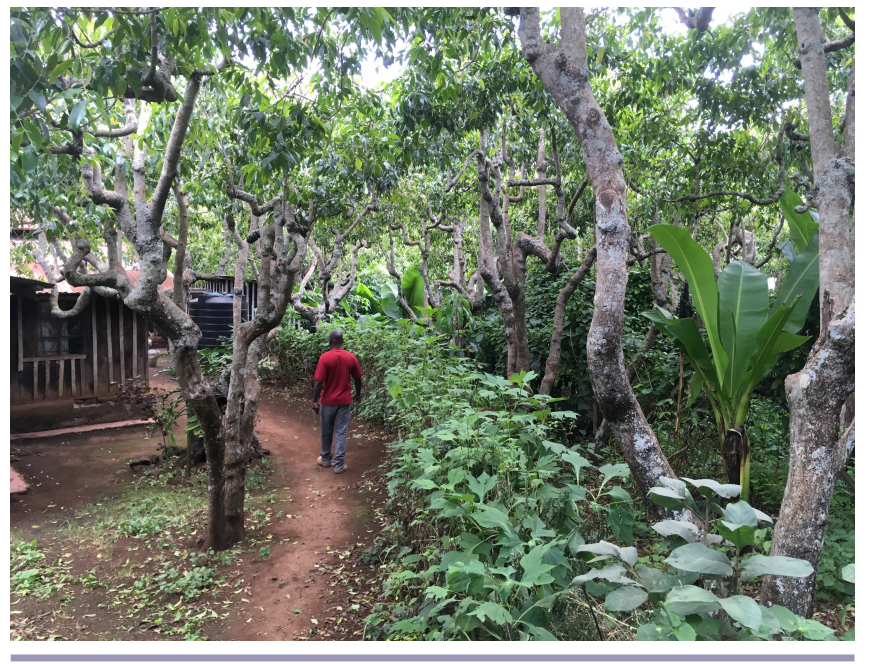

Fig. 3. Commercial khat (Catha edulis) farm with small monocropped khat bushes.

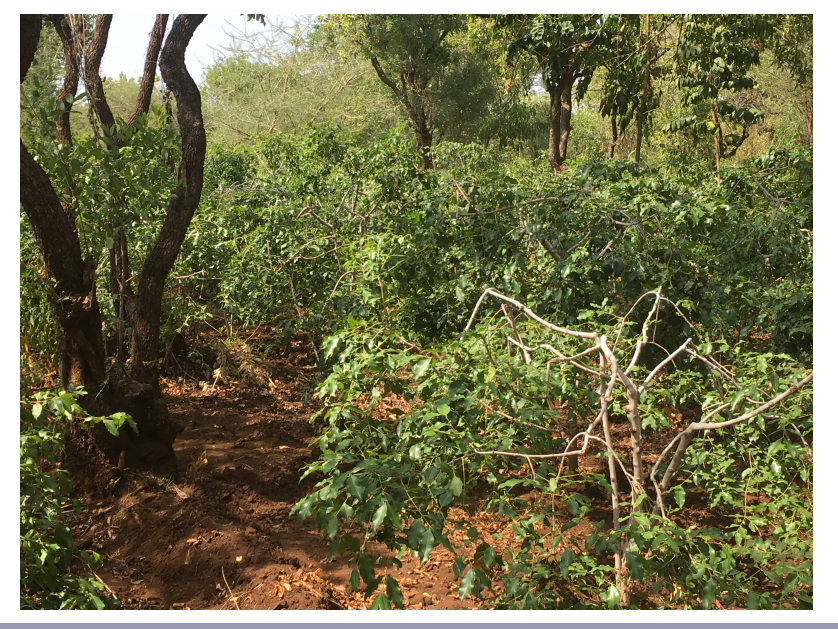


traditional areas of cultivation, as distinguished from commercial areas, include: (1) use of traditional pruning techniques; (2) intercropping; (3) traditional insect control, e.g., smoke; (4) rainfed rather than irrigated cropping systems; (5) preference for allowing khat trees to grow big and old; (6) farmers' emotional attachment to khat trees; and (7) traditional meanings and uses of khat, e.g., as something for a man to bring to a prospective bride's family to secure marriage. These factors are sometimes present in the commercial areas but are exceptions rather than integral parts of the commercial farming system.

The centers of traditional khat production like Muringene are well-known; new areas of production on the other hand are sometimes labeled as commercial at first but then later can become more traditional. Even Njuri influence, according to some Njuri elders, can spread to commercial areas as time goes on. Goldsmith, doing research in the 1990s, reported on the local view that people around Ntonyiri (Laare) were engaging in more commercial (as compared to traditional) khat production, involving lower quality khat, pesticide applications, monocropping, and the use of farming ideas from school rather than neighborhood knowledge networks (Goldsmith 1994). By 2019, most farmers around Laare had the same degree of intercropping, plant diversity, and reservations about pesticide as farmers in other areas of traditional khat production like Muringene and Njia. This might indicate that some areas of commercial production can become more traditional as time goes on and khat trees become bigger and more established.

Khat is a highly valuable cash crop that is sold in Kenya and abroad. Prices for khat are variable, depending on the variety of khat, the age of the tree (with older mbaine trees producing the highest quality and highest priced shoots), and the season, with prices going up in the dry season when khat trees are less productive. On average, khat coming from commercial farms is considered in Igembe to be of lower quality and poorer taste and tends to go to the export market.

\section{Theoretical framework for state law, social institutions, and pesticides}

Although our research tests for how effective the Njuri Ncheke is at controlling pesticide on khat, the theoretical puzzle is about why, if such institutions can be proven effective, the state has such a difficult time working with the Njuri Ncheke to further public policy goals.

Social institutions, in this framework, would include professional associations, workplaces, families, and all kinds of customary groups like the Njuri Ncheke. They can be more or less structured. Nonstate social institutions with internal structure and decisionmaking capabilities have been shown to be effective partners in regulating farming and, in particular, at regulating activities on shared commons. The reasons for their general efficacy and legitimacy have been established through case studies and depend on context. Such reasons include: people are more likely to obey rules that they participate in making and enforcing, social institutions offer less costly monitoring and enforcement for some problems than public or private policing professionals, and social institutions are more adaptable to complex ongoing working conditions (Ostrom 1990, Ellickson 1991, Berkes 1999, Bosselman 2005, Cox et al. 2014, Noe and Alrøe 2015).
The relationship between state law and nonstate social institutions is a thorny issue without a strong theoretical framework. For a long time, legal scholars insisted on separating out the state legal system as a final arbiter of other institutions' authority. The state legal system, in other words, serves as a centralized metainstitution that determines jurisdiction for all state and nonstate institutions under it (Sage and Woolcock 2012). This view is giving way to a more relational approach (e.g., Eisenberg 2019). That is, state law as a system of social control is seen to work only with the cooperation of social institutions whose rulemaking authority overlaps with state law. For example, a person obeys criminal law not just out of fear of going to prison, but out of fear that going to prison will harm his reputation among his peers and signal future employers not to hire him.

The state partners with some social institutions more easily than others. In particular, the state has difficulty partnering with religious groups, communal property groups, and other customary organizations that apply rules contrary to modern ideals like individual independence and mobility, professionalism, and freedom to acquire property and contract with others. In the history of relations between state law and customary authorities in Africa, for example, state law reformers have repeatedly tried to co-opt customary authorities or sideline them or eliminate them altogether (Keyd and Buur 2007). In contrast, state actors have cooperated with institutions staffed with people like them, for example, corporations with professionals who are accountable to their professional group (through degree requirements and licensing) and who can fill forms and create a paper trail in a format that is legible to the state. Partnerships between state regulatory agencies and the corporations that they regulate are often so intimate, including exchange of personnel, that the state agency and its set of regulations is said to be "captured" by industry.

It is strange that the state is biased in favor of state-corporate partnerships to regulate pesticide, considering the partnership's track record of failure. Although successful in eliminating particular harmful chemicals like DDT, professional rules supported by administrative agencies and corporate regulated parties have not reduced the total amount and variety of agrochemicals used. Countries like the U.S. and Germany, both of which have expended considerable money and regulatory effort to control pesticides, have not lessened overall quantities of pesticide applied nor dealt adequately with cumulative risk (Knudsen 2017, EEA 2018). The risk analysis of professionals has tended to have a narrow focus, for example, in the pesticide registration process on the toxicity of active ingredients. State law has been less willing to accept more holistic risk appraisals and criticisms from indigenous groups, food sovereignty groups, and others who sense in pesticides larger disruptions to farmers' and others' ways of life.

Another problem with state-corporate partnerships for pesticide regulation is that the partnership is not delivering on its promise to reduce the administrative costs of regulating farmers. As explained already, state law partners with social institutions like corporations in part to achieve administrative cost savings, i.e., to get private parties to regulate themselves according to their own rules but in ways that also achieve state goals. Private regulation schemes like GlobalGAP promise such administrative 
cost savings, with large-scale farmers self-monitoring and reporting pesticide applications to meet the food standards of grocery retailers. In practice, the state has had to subsidize this type of private regulation, particularly when applying standards to small-scale farms. The image of the smallholder freely following farming rules that he or she has helped to create is false. In Kenya for example, vegetable farmers exporting to the EU have had to be organized into farmers' groups, which then still must be policed, at high cost, by the state, by GlobalGAP certifiers, and by exporters (Humphrey 2008, Ouma 2010, Tallontire et al. 2014).

Integrated pest management (IPM) programs are a better prototype for states trying to partner with social institutions to reduce the cost of regulating farmers. Indeed, IPM has been effective at reducing overall pesticide use, but its success has been misinterpreted (Pretty and Bharucha 2015). Integrated pest management is typically understood as being about farmer innovation and about combining chemical and nonchemical strategies for tackling pest problems. This misses the critical role in IPM of farmer field schools, which are in part a social accountability tool. Farmer field schools expose farmers' practices to other farmers and to agricultural extension officers. This makes using less pesticide a meaningful activity through social exposure and achieves some low-cost regulation.

The state has worked only selectively with some social institutions to regulate pesticides, and, where it has partnered with farmers as in IPM, the state has not understood the social dimension of its successes very well.

\section{METHODS}

\section{Pesticide residues on khat}

\section{Sample collection}

Khat samples were taken from four traditional khat-producing areas (Laare, Muringene, Njia, Nkandone) and from three commercial areas (Antubochiu, Athiru Gaiti, and Meru National Park) in Igembe. Within each area, we sampled khat from 5 different farms selected at random (except Njia where we had only 4 samples), for a total of 34 samples. These samples were analyzed for pesticide residues.

\section{Sample preparation}

Air-dried leaf samples were extracted by a modified QuEChERS procedure and screened for 258 pesticides, including some metabolites and breakdown products, by liquid chromatography mass spectrometry (LC-MS/MS).

Five grams of air-dried leaves were extracted with $10 \mathrm{~mL}$ of acetonitrile/water (1:1, v/v) and homogenized using approximately $8 \mathrm{~g}$ of ceramic beads and a Bead Ruptor 24 (OMNI International, USA). After complete homogenization, $6.5 \mathrm{~g}$ of EN 15662 salts were added (4 g MgSO4; $1 \mathrm{~g} \mathrm{NaCl} ; 1 \mathrm{~g}$ sodium citrate tribasic dihydrate; $0.5 \mathrm{~g}$ sodium citrate dibasic sesquihydrate). Samples were then shaken and centrifuged at $7300 \times \mathrm{g}$ for 5 minutes. After centrifugation, $1000 \mu \mathrm{l}$ of supernatant was collected and transferred into a d-SPE (dispersive solid phase extraction) tube containing $150 \mathrm{mg}$ PSA, $900 \mathrm{mg} \mathrm{MgSO} 4$. After the d-SPE step, $198 \mu \mathrm{L}$ of sample was collected and $2 \mu \mathrm{L}$ of internal standard solution $\left(\mathrm{d}_{4}\right.$-imidacloprid $0.07 \mathrm{ng} / \mu \mathrm{L} ; \mathrm{d}_{5}$-pyrimethanil $0.01 \mathrm{ng} / \mu$ L) was added. Samples were filtered, $0.22 \mu \mathrm{m}$, polytetrafluoroethylene
(PTFE), and analyzed immediately by liquid chromatographyelectrospray ionization-mass spectroscophy (LC-ESI-MS/MS).

Liquid chromatography (LC) and mass spectrometry Sample analysis was carried out with a Vanquish Flex UHPLC system (Dionex Softron GmbH, Germering, Germany) coupled with a TSQ Quantis mass spectrometer (Thermo Scientific, San Jose, California). The UHPLC was equipped with an Accurcore aQ column $(100 \mathrm{~mm} \times 2.1 \mathrm{~mm}, 2.6 \mu \mathrm{m}$ particle size $)$. The mobile phase consisted of (1) methanol/water $(2: 98$, v/v) with $5 \mathrm{mM}$ ammonium formate and $0.1 \%$ formic acid and (2) methanol/water $(98: 2, \mathrm{v} / \mathrm{v})$ with $5 \mathrm{mM}$ ammonium formate and $0.1 \%$ formic acid. The temperature of the column was maintained at $25^{\circ} \mathrm{C}$ throughout the run and the flow rate was $300 \mu \mathrm{L} / \mathrm{min}$. The elution program was as follows: $1.5 \mathrm{~min}$. equilibration $(0 \% \mathrm{~B})$ prior to injection, $0-0.5 \mathrm{~min}$. ( $0 \% \mathrm{~B}$, isocratic), 0.5-7 $\mathrm{min}$. $(0 \%-70 \% \mathrm{~B}$, linear gradient), 7-9 min. (70\%100\% B, linear gradient), 9-12 min. $(100 \% \mathrm{~B}$, column wash), $12-12.1 \mathrm{~min}$. (100\%-0\% B, linear gradient), and 12.1-14.5 $\mathrm{min}$. ( $\% \% \mathrm{~B}$, re-equilibration). The flow from the LC was directed to the mass spectrometer through a heated electrospray probe (H-ESI). The settings of the H-ESI were: spray voltage $3700 \mathrm{~V}$ for positive mode and $2500 \mathrm{~V}$ for negative mode, sheath gas 35 (arbitrary unit), auxiliary gas 8 (arbitrary unit), sweep gas 1 (arbitrary unit), ion transfer tube temperature $325^{\circ} \mathrm{C}$, and vaporizer temperature $350^{\circ} \mathrm{C}$. The MS/ MS detection was carried out using the selected reaction monitoring (SRM) mode. Two transitions were monitored for each compound: one for quantification and the other for confirmation. The resolution of both Q1 and Q3 was set at 0.7 FWHM (full width at half maximum). The cycle time was 0.5 seconds and the pressure of the collision gas (argon) was set at 2 mTorr.

\section{Comparing residue data from traditional and commercial areas}

Taking the chemical residues found in the samples, we compared the quantity of residue from traditional areas with the quantity from commercial areas. The significance of the difference was determined using permutational multivariate analysis of variance (PERMANOVA; 999 permutations; adonis2 in vegan R package; Anderson 2001). A pair-wise two-sample permutation test was conducted for pesticide residues, with the Benjamini-Hochberg adjustment for multiple comparisons (Benjamini and Hochberg 1995). All the data analysis was done using R3.4.2 software (R Development Core Team 2017).

\section{Qualitative interviews}

\section{Background interviews}

Khat farmers were interviewed and observed on multiple visits to Igembe from 2014 to 2015 and again from 2017 to 2019. These interviews, which were mainly conducted in Kimeru with the aid of an interpreter, were semistructured and concerned khat farming and Igembe social institutions. They included farm tours, discussions with farmers and elders, and observations of public Njuri meetings.

\section{Farmer surveys}

To gather specific information about farmer pest control strategies and the influence of the Njuri on pest control, we conducted a farmer survey of 47 khat farmers from the 7 areas where we took khat samples. Survey participants were selected at random in each of the seven areas and were asked a set of questions in Kimeru through an interpreter. 
Table 1. List of pesticide residues from khat samples grown under traditional and commercial production systems. Note: $\mathrm{MRL}=$ maximum residue limits.

\begin{tabular}{|c|c|c|c|}
\hline & \multicolumn{3}{|c|}{ Pesticide residue (amount $\pm \mathrm{SE}$ in $\mathrm{mg} / \mathrm{kg}$ ) in different production systems } \\
\hline & Traditional production system & Commercial production system & EU MRLs for teas \\
\hline \multicolumn{4}{|l|}{ Insecticides } \\
\hline Acephate & - & $0.0822 \pm 0.0428$ & $0.05^{*}$ \\
\hline Avermectin B1a & - & $0.0271 \pm 0.0237$ & 0.05 \\
\hline Carbaryl & $0.0001 \pm 0.0000 \mathrm{a}$ & $0.0002 \pm 0.0001 \mathrm{a}$ & 0.05 \\
\hline Chlorpyrifos & $0.0001 \pm 0.0000 \mathrm{a}$ & $0.0243 \pm 0.0228 b$ & 0.05 \\
\hline Methamidophos & - & $0.0119 \pm 0.0078$ & 0.05 \\
\hline Profenophos & - & $0.0183 \pm 0.0127$ & 0.05 \\
\hline \multicolumn{4}{|l|}{ Fungicides } \\
\hline Hexaconazole & - & $0.0051 \pm 0.0044$ & 0.05 \\
\hline Thiophanate-methyl & - & $0.0642 \pm 0.0641$ & 0.1 \\
\hline \multicolumn{4}{|c|}{$\begin{array}{l}\text { Values in a row (between each khat production system), followed by the same letter, are not significantly different at } P=0.05 \text {. } \\
\text { - indicate absence of the pesticide residue. } \\
* \text { indicate MRLs above the EU's recommended MRLs for teas and other herbal infusions from dried product. } \\
\text { Out of } 258 \text { chemical pesticides including their metabolites tested, only eight chemical compounds residues were detected in the khat } \\
\text { samples. }\end{array}$} \\
\hline
\end{tabular}

Follow-up meeting with the local Njuri Ncheke

After completing our residue analysis and farmer surveys, we presented some of our results for discussion at a meeting of one of the local Njuri Ncheke councils in Ntonene (near Laare). Participants offered comments on our hypothesis about the Njuri's role in pesticide control. Overall, the Njuri expressed some optimism about expanding their influence in the future into commercial areas of production.

\section{RESULTS}

\section{Pesticide residues in khat samples}

We observed both qualitative and quantitative differences in pesticide residues between traditional and commercial production systems $\left(\mathrm{F}_{1,32}=9.008, P=0.001\right)$. Qualitatively, only two pesticide residues were found in khat samples from the traditional production system compared to eight different pesticide residues from the commercial production system (Table 1). Pesticide residue was affected by the type of khat production system, with khat plants grown under commercial production having higher quantities and more diverse pesticide residues compared to those grown under traditional production (Table 1). Major categories of detected pesticide residues were insecticides and fungicides (Table 1). Additionally, individual sites on which commercial production of khat was carried out had higher amounts of pesticide residue compared to individual sites where khat was produced under the traditional production system (Table 2).

\section{Environment and health impacts}

Maximum residue limits (MRLs) for khat are not available. Instead we approximated MRLs for khat by using European Union MRLs for teas and herbal infusions from dried products (https://www.ec.europa.eu/food/plant/pesticides/eu-pesticides-database/ public/). Using the EU MRL standard for tea, the only likely residue exceedance was for acephate, an insecticide used mainly to control aphids and caterpillars.
Table 2. Pairwise comparison in khat (Catha edulis) is for all pesticide residues found in each specific site, $n=7$. Bolded names indicate traditional production system whereas unbolded names indicate commercial production system.

\begin{tabular}{|c|c|c|c|c|c|c|}
\hline $\begin{array}{l}\mathrm{S} / \\
\mathrm{NO}\end{array}$ & Pairs & Df & $\begin{array}{l}\text { Sum } \\
\text { of } \\
\text { Sqs }\end{array}$ & $\begin{array}{c}\text { F. } \\
\text { Model }\end{array}$ & $\mathrm{R}^{2}$ & $P$ value \\
\hline 1 & $\begin{array}{l}\text { Muringene vs Meru } \\
\text { National Park }\end{array}$ & 1 & 0.690 & 1.884 & 0.191 & 0.055 \\
\hline 2 & Muringene vs Athiru Gaiti & 1 & 1.035 & 3.245 & 0.289 & 0.007 \\
\hline 3 & Muringene vs Laare & 1 & 0.861 & 4.047 & 0.336 & 0.012 \\
\hline 4 & Muringene vs Nija & 1 & 0.544 & 2.156 & 0.235 & 0.044 \\
\hline 5 & Muringene vs Nkandone & 1 & 0.635 & 2.495 & 0.238 & 0.074 \\
\hline 6 & Muringene vs Antubochiu & 1 & 0.769 & 2.179 & 0.214 & 0.065 \\
\hline 7 & Laare vs Njia & 1 & 0.266 & 3.667 & 0.344 & 0.031 \\
\hline 8 & Laare vs Nkandone & 1 & 0.041 & 0.420 & 0.050 & 0.596 \\
\hline 9 & Laare vs Antubochiu & 1 & 1.140 & 5.822 & 0.421 & 0.008 \\
\hline 10 & Njia vs Nkandone & 1 & 0.194 & 1.617 & 0.188 & 0.229 \\
\hline 11 & Njia vs Antobochiu & 1 & 1.166 & 5.008 & 0.417 & 0.023 \\
\hline 12 & Nkandone vs Antubochiu & 1 & 0.944 & 3.978 & 0.332 & 0.018 \\
\hline 13 & $\begin{array}{l}\text { Meru National Park vs } \\
\text { Athiru Gaiti }\end{array}$ & 1 & 0.720 & 2.287 & 0.222 & 0.053 \\
\hline 14 & $\begin{array}{l}\text { Meru National Park vs } \\
\text { Laare }\end{array}$ & 1 & 0.821 & 3.931 & 0.329 & 0.009 \\
\hline 15 & Meru National Park vs Njia & 1 & 0.983 & 3.969 & 0.362 & 0.003 \\
\hline 16 & $\begin{array}{l}\text { Meru National Park vs } \\
\text { Nkandone }\end{array}$ & 1 & 0.690 & 2.755 & 0.256 & 0.010 \\
\hline 17 & $\begin{array}{l}\text { Meru National Park vs } \\
\text { Antubochiu }\end{array}$ & 1 & 0.115 & 0.330 & 0.040 & 0.758 \\
\hline 18 & Athiru Gaiti vs Laare & 1 & 1.590 & 9.850 & 0.552 & 0.003 \\
\hline 19 & Athiru Gaiti vs Njia & 1 & 1.475 & 7.620 & 0.521 & 0.005 \\
\hline 20 & Athiru Gaiti vs Nkandone & 1 & 1.382 & 6.808 & 0.460 & 0.006 \\
\hline 21 & Athiru Gaiti vs Antubochiu & 1 & 0.759 & 2.515 & 0.239 & 0.035 \\
\hline
\end{tabular}

Nonetheless, because khat is often consumed directly from the tree, with no processing or washing, our MRL standard is more likely to underestimate the potential harmful impact. Many khat chewers consume khat every day, presenting the danger of accumulating chemicals in their bodies over time. Farmers often 
spray without protective gear and do not dispose of pesticide containers properly, thus presenting other pathways to harmful contamination. In addition, the accumulation of pesticides in the environment can harm nontarget plants and animals, including pollinators like bees. This in turn can have a negative impact on crop production that depends on pollination, as well as honey production. Indeed, acephate is known to be highly toxic to bees and other beneficial insects.

\section{Results from background interviews}

Background interviews with khat farmers and Igembe elders took place over several years and did not follow a script. These interviews are separate from the farmer survey conducted in 2019. During interviews, farmers made two major claims repeatedly: first, that the Njuri Ncheke had banned the spraying of pesticides on or around khat trees in Igembe, and second, that the farmers respected the Njuri in general, and the ban specifically, and feared the rituals and curses of the Njuri (see also Krueger 2016).

Although this was the general opinion among interviewees, a few others expressed doubts about whether total compliance with the pesticide ban was being achieved. They claimed that some farmers sprayed at night to avoid detection. Other evidence indicated that some pesticides were being used on khat farms, though perhaps not directly on khat trees. This evidence included debris from pesticide packaging found on farms and first-hand observations of spraying other crops nearby khat trees.

All farmers in Igembe have at least some access to pesticides, typically at local agrochemical stores. At stores, farmers learn about and purchase pesticides for crops other than khat. Other farmers and agricultural extension officers also share information about which pesticides to use for which pests. This knowledge is transferred over to khat farming. This situation is changing somewhat because khat has become more accepted as a modern commercial crop. The private company Greenlife, for example, has published a set of recommended pesticides for khat farmers on its website (https://www.greenlife.co.ke/overcome-miraachallenges-this-season/).

Njuri Ncheke elders in Igembe confirmed that they had banned pesticide spraying on and around khat trees. They reported taking several measures: convening public meetings to generate a consensus for banning pesticides on khat (reported also in Carrier 2007); performing rituals such that farmers who spray their khat will incur a curse; and directly warning and threatening farmers who are caught using pesticide (and, in at least one case, uprooting the khat trees of a farmer who was openly spraying his khat). Government officers (like chiefs) have at times also warned farmers to obey the Njuri ban against pesticide on khat (reported in Goldsmith 1994). When asked about why they banned pesticides, Njuri elders talked about how khat is chewed fresh from the tree and how pesticides pose serious health risks.

\section{Results from the farmer survey}

The farmer survey confirmed the pesticide residue analysis. Farmers from traditional khat producing areas were far less likely to be using pesticides, with 4 out of 24 spraying pesticides, compared to 23 out of 23 spraying pesticides in commercial areas (Table 3).

Traditional farmers also were far more likely to apply traditional insect controls like smoke; more likely to have older khat trees on their farms; and more likely to report some interactions with the Njuri. Importantly, all 47 farmers across traditional and commercial areas reported similar pest problems, despite varying microclimates, with most farmers complaining of aphids, worms, caterpillars, and blight. Almost all commercial farmers used irrigation on their khat trees, whereas none of the traditional farmers did. Finally, commercial farmers are not necessarily distinguished by having larger sized farms. Many commercial farmers, particularly in Athiru Gaiti and Antubochiu, are smallholders with plot sizes comparable to traditional farmers.

Table 3. Farmer survey (47 respondents).

\begin{tabular}{lcc}
\hline \hline & $\begin{array}{c}\text { Traditional khat } \\
\text { farmers } \\
\text { (24 respondents) }\end{array}$ & $\begin{array}{c}\text { Commercial khat } \\
\text { farmers } \\
(23 \text { respondents })\end{array}$ \\
\hline $\begin{array}{l}\text { Currently spraying } \\
\text { khat }\end{array}$ & $17 \%$ & $100 \%$ \\
$\begin{array}{l}\text { Currently using } \\
\text { traditional pest } \\
\text { deterrent (smoke) }\end{array}$ & $63 \%$ & $9 \%$ \\
$\begin{array}{l}\text { Currently using } \\
\text { irrigation on khat }\end{array}$ & $0 \%$ & $\begin{array}{c}95 \% \\
\text { Average age of oldest } \\
\text { trees on farm } \\
\text { Average plot size }\end{array}$ \\
\hline
\end{tabular}

\section{DISCUSSION}

Njuri interventions and reduced pesticide use on traditional farms The evidence of greater pesticide residues in commercial khat compared to traditional khat, together with farmer interviews, provides strong support for our hypothesis. Njuri interventions are reducing pesticide residues on traditional khat farms.

As pesticides have become more readily available in Igembe, more smallholder farmers use them on a variety of crops. The incentives and interest to use pesticides are clear. All khat farmers who were interviewed reported problems with aphids and caterpillars in the canopy, fungal blight appearing as spots on khat leaves, and insect larvae that harm khat roots. All farmers are aware of, and have access to, various pesticides that can alleviate some of these problems. And indeed, pesticide residue can be found on khat across Igembe, even on traditional farms. The small amount of residue that we found on traditional khat farms might not be from directly spraying khat but from spraying other crops like maize, beans, and potatoes that are intercropped with khat trees, or from pesticide drift in the air or from water runoff from other locations that the plants absorb when taking up water through their roots.

We asked whether differences in microclimate might also explain some of the variations in pesticide use between traditional and commercial areas. For example, the frequency and intensity of pest invasions might be greater in some of the commercial areas, even if the types of pests are similar, thus requiring a more intense chemical regimen. With its hilly topography, Igembe does indeed have multiple microclimates. Two of the areas of commercial khat production, Meru National Park and Athiru Gaiti, are distinguishable for slightly higher temperatures, lower elevation, and lower rainfall. Antubochiu, another commercial area, has 
slightly higher rainfall but is similar in elevation to the traditional areas of cultivation.

Additional evidence suggests that the Njuri, rather than the climate conditions or the prevalence of pests, is causing fewer pesticides to be used on traditional farms. First, farmers themselves attribute less pesticide use to the Njuri. This is exemplified by two of the traditional farmers in the survey, and others in background interviews, who admitted trying pesticide in the past but then later discontinuing it after the Njuri banned it. Also, many of the traditional farmers indicated that they use traditional remedies against pests, mainly smoking them out. Only two of the commercial farmers also said that they use such traditional alternatives to pesticides. Rather, it would seem that commercial farmers are using chemicals in place of more laborintensive traditional practices, rather than using chemicals for unique pest challenges where they are farming.

\section{The Njuri as an effective nonstate decision maker}

Although the Njuri is a unique institution of the Meru, the way that the Njuri has addressed pesticides offers important lessons for how social institutions work. The effectiveness of the Njuri is not a predetermined outcome to be explained by a set of generalizable factors, but rather comes out of an iterative process of localized decision making.

The Njuri deliberated, repeatedly, over the pesticide problem and has worked toward a consensus with farmers over time. It did not make rules and impose them strictly but rather mobilized its authority and nudged people toward compliance. Njuri curses for spraying khat are effective, but they work indirectly, by identifying pesticide spraying on khat as a kind of wrong, and rallying social pressure against people who spray.

It is not just that the Njuri is making decisions, but also that its decision making is holistic and values-based. The Njuri did not come into being to manage khat, or to control pesticides, or to manage pastures or forest commons, although it has undertaken all of these jobs and more, with the help of other institutions like clans and age set councils. When asked about the Njuri's involvement in their lives and farms, farmers mentioned a variety of things, for example, that the Njuri resolve property disputes and deal with family tensions and marital problems. The Njuri is applying principles of justice and public good to problems in the community and working out their policy priorities with their members and the broader Igembe community in an on-going process. Other scholars writing about social institutions have made similar arguments (e.g, Cleaver 2002, Fabinyi et al. 2014).

To focus on an institution's decision making is to apply ideas from legal theory to social institutions. Many legal scholars, although appreciating the determinism of clear rules, also appreciate that the law inevitably must allocate discretion to decision makers in complex situations (e.g., Braithwaite 2002). Scholars of social institutions, in contrast, tend to talk about institutions following a predetermined logic (for example, explaining when institutions will self-organize). Acknowledging decision-making processes and discretion is the better approach, in our view, and one which draws needed attention to the related issue of how we make decision makers accountable.

If institutions can be seen to be exercising some discretion, i.e., making decisions and adjusting rules and principles for specific problems, then this opens them up to discussions of accountability and improvement. The Njuri case furthermore suggests an alternative path for research interventions, with researchers helping to highlight and confirm successful management outcomes on a case-by-case basis, while leaving space for diversity and experimentation in nonstate decision making.

\section{State bias against certain types of social institutions}

If the Njuri can be shown to be effective, and state actors are somewhat aware of this (as many local Kenyan officials in Igembe are), why then does the state tend to ignore Njuri successes and opt to partner with other social institutions? Some of the very things that make the Njuri effective, like its holism, its connection to Igembe spirituality, and its iterative and slow-moving decisionmaking process, make it unattractive to state actors. And state decisions about who to partner with are not necessarily about effectiveness.

The Njuri has a different process from the state for determining the risks of pesticides and weighing risks against potential benefits. This process involves taking a cautious approach to technological innovations like pesticides, building consensus among farmers about the problem of pesticides and public health, and considering much wider impacts (for example, on future generations). The Njuri also takes a different approach to enforcement, opting for a total ban on pesticides instead of complex rules of use that must be implemented by others, like requiring a waiting period after spraying pesticides and before harvesting.

From an individual rights perspective, social institutions like the Njuri can appear inconsistent, illiberal, and hierarchical (e.g., Dagan and Heller 2001, Sagy 2011). Njuri regulatory techniques, which take legitimacy from Igembe traditions and involve the use of curses, go against a number of individual rights, like the right to choose one's religion and the right to choose where to live and what values one will be subjected to in that place, or the rights of women to participate in regulatory decision making for that matter. Like other social institutions, the Njuri is ultimately threatening social exclusion and spiritual or even physical harm as punishment for wrongdoing (see also Colding and Folke 2001, Cox et al. 2014, Helbling et al. 2015). Mechanisms for enforcing rules might appear alternatively too extreme, i.e. making an example of someone to strike fear in the hearts of the many people whose rule breaking is not visible or reachable, or too weak and irregular, i.e., having escalating threats and sanctions that tolerate a lot of rule breaking before cracking down.

Although the inner workings of social institutions like the Njuri are messy, the narrative of modernization, that state law and professionals will clean up this messiness, is increasingly criticized. Scholars find, for example, that state institutions have similar flaws of hierarchy and informal irregularities in day-to-day practice (e.g., De Herdt and Olivier de Sardan 2015). And there is some movement toward a compromise position between the rights of individuals (realized through state law interference in groups) and the rights of nonstate groups to make their own internal rules and be free from state interference (e.g., Eisenberg 2019).

Nonetheless, it is the modernization narrative that prevails when it comes to the question of which social institutions the state 
chooses to partner with. When taking up khat as a matter of agricultural policy, the Kenyan government framed its initiative in terms of a modernization narrative. In this narrative, the lack of standardized rules for farming and trade hamper the khat business, an assertion which is not true. This approach, which builds up the government's authority and provides a justification for professional intervention, precludes recognizing the past efforts of the Njuri, a nonprofessional institution that has already succeeded in doing some of the things that the government is saying it needs to intervene to get done.

Until recently, the government was not involved in khat farming, except that the government, like many governments around the world, considered implementing regulations to label khat as a drug and restrict its consumption (Anderson and Carrier 2009, Carrier and Klantschnig 2018). Since 2016, however, the government of Kenya has recognized khat formally as a cash crop and has taken a variety of measures, like allocating funding, proposing draft khat regulations, and setting up a "Miraa, Pyrethrum and Other Industrial Crops Directorate."

Regulating pesticide in khat is also on the government's agenda. The government has had some related experience controlling pesticide on export crops in the vegetable sector through the Horticulture Crops Directorate (HCD). Here, the government partners with a variety of nonstate institutions to try to manage pesticides, with limited success. In the pesticide registration process, the government partners with professional institutions and universities, employing experts, both public experts at the Pesticide Control Products Board and private experts in the employ of agrochemical companies, to determine which particular pesticides are toxic and under what conditions.

Once a particular pesticide product has been determined safe and allowed onto the market, the decisions about costs-versusbenefits of particular pesticide applications, i.e., of how much pesticide is safe in a particular place, are allocated to people affiliated with nonstate institutions, for example, licensed agricultural extension professionals (in public and private employ), pesticide trainers, and agrochemical stores, among others. Kenyan agricultural extension officers, for example, promote some types of pesticides that other Kenyan agencies and the EU try to restrict, and they tend to prescribe synthetic pesticides over IPM and other types of nonchemical remedies for pests (Ochilo et al. 2018). In the vegetable export sector, farmers employ people to keep records of pesticide applications and ensure traceability (of produce back to the farmer).

The successful modernization of the vegetable export sector is an impressive example of working with a particular set of social institutions to organize agricultural supply chains. Being organized, professional, and modern does not in itself achieve the public policy goal of less dependence on synthetic pesticides, however. Indeed, when viewed from the perspective of holism, this approach can be seen to have a number of negative side effects on local farming. It is expensive for one, such that this system of accountability favors large scale farmers and can run up the cost of agricultural produce. It can also have the effect of simplifying farming processes, stymying farmer innovation, and discouraging nonstandard pest control strategies like landscape diversity (Karp et al. 2015, 2016, Pollans 2015).

\section{Accountability and pesticide use}

Our study also touches on the broader literature about who is responsible for pesticide overuse. The focus of much of this literature has been on factors external to the farm. For example, farmers are said to be on a technology treadmill, in which increased productivity drives down the price that farmers get from agricultural products and selects for large-scale farmers who can finance further intensification and more agrochemicals (Levins and Cochrane 1996). Or, relatedly, farmers might be caught in a debt trap in which loans to finance intensification can only be paid off by even more intense agricultural practices (Luna 2020). Agrochemical companies also influence government policy so that government programs to subsidize inputs are set up to get farmers hooked on agrochemicals. Or, farmers are driven to use more agrochemicals through the power politics of knowledge and the direct influence of advertising, industry-financed studies supporting agrochemicals, and subtle misinformation against alternative practices (Harrison 2020).

With regard to how information about agrochemicals is being distorted at the level of state policymaking, the above theories offer great insight. However, these theories cannot account for all of the increases in demand for pesticides across contexts. These theories also paint farmers into a corner of seeming helplessness and unaccountability, setting up the problem of pesticides so that it is not solvable. We are forced to ask for accountability and reform initiative from the existing partnership of state law and powerful political actors, like agrochemical companies, that are least likely to act.

Our case study is an important counterexample of farmers both seeking out cheap pesticides on their own initiative and finding ways to limit agrochemical use by collective decision making. It is a unique example because the Njuri is a unique institution of the Meru, but it also holds out hope for successful local regulation by different types of local institutions over complex farming technologies like pesticides. And the Njuri's success fits within broader narratives of food sovereignty, of giving small-scale farmers greater discretion and autonomy to regulate their own farming practices and local economies.

\section{CONCLUSION}

Our study stresses both the importance and the difficulty of creating a state law framework within which nonstate institutions can monitor and enforce rules. If successful problem solving by social institutions is idiosyncratic, as with the Njuri, it can nonetheless be evaluated empirically by researchers, as we have done. This provides evidence to support the case for more autonomy for the Njuri, particularly when it comes to managing pesticides on traditional khat farms. It also suggests that the state should differentiate among types of farmers and focus formal regulation on a certain class of farmer, in our case, on commercial khat farmers in specific locations.

Governments need to rethink how to monitor and enforce complex agricultural rules, like limitations on pesticide use. There are obvious and necessary administrative cost savings to partnering with social institutions of some form. State law is currently looking for these cost savings through a variety of forms of corporate "private" rule-setting, for example, private GlobalGAP agricultural production standards. Kenya's own regulatory agencies like Kenya Plant Health Inspectorate Service 
(Kephis) provide pesticide testing services and other regulatory supports like farm inspections and export certifications for private GlobalGAP certified farmers who are exporting vegetables to Europe.

Such private standards, even with government subsidies, are still very expensive to administer and do not have the same coercive and normative potential of public accountability to neighbors as well as to consumers. What makes them attractive over indigenous institutions like the Njuri is simple bias in favor of that which seems technocratic and modern. The state should not be biased either way, either for or against corporate standards, or for or against the Njuri. The measure of successful pesticide management should be simply the most compliance and greatest reduction in pesticide use per lowest administrative cost.

More outcome-focused research is needed on social institutions in agriculture, with greater tolerance for their diversity of approaches. Important but tricky theoretical issues include: (1) how to promote human rights norms without overly constraining nonstate institutions' autonomy; (2) how to get state officials, who have a vested interest in their own professional authority, to delegate some of their regulatory power to nonexperts; and (3) how to pursue rational policy goals in situations of great complexity and unpredictability, in which rule interventions, by the state or by social institutions, will have many unintended side effects.

Responses to this article can be read online at: http://www.ecologyandsociety.org/issues/responses. $\mathrm{php} / 11916$

\begin{abstract}
Acknowledgments:
We are grateful to Igembe khat farmers for allowing us to collect khat samples from their farms and Njuri Ncheke members for cooperation throughout the study. We thank Mwenda Mauta for assisting in field sample collection, Professor William Baariu Ncene for his wisdom and guidance, and Nicolas Jean-Baptiste Baert for assistance in pesticide residue analysis. Funding for the project was provided by the Atkinson Center for a Sustainable Future at Cornell University. We also recognize our respective institutions, Mekelle University, SEKU, and ICIPE, for supporting us as we prepared this article. ICIPE acknowledges financial support from its core http://www.icipe.org/donors-and-partners/core-donors and project donors http://www.icipe.org/donors-and-partners/project-donors.
\end{abstract}

\section{Data Availability:}

The datalcode that support the findings of this study are presented in tables in the article. Any additional data are available on request from the corresponding author, JSK.

\section{LITERATURE CITED}

Adjognon, S. G., L. S. O. Liverpool-Tasie, and T. A. Reardon. 2017. Agricultural input credit in Sub-Saharan Africa: telling myth from facts. Food Policy 67:93-105. https://doi.org/10.1016/ j.foodpol.2016.09.014
Anderson, D., and N. Carrier. 2009. Khat in colonial Kenya: a history of prohibition and control. Journal of African History 50:377-397. https://doi.org/10.1017/S0021853709990752

Anderson, M. J. 2001. A new method for non-parametric multivariate analysis of variance. Austral Ecology 26(1):32-46.

Benjamini, Y., and Y. Hochberg. 1995. Controlling the false discovery rate: a practical and powerful approach to multiple testing. Journal of the Royal Statististical Society: Series B. 57:289-300. https://doi.org/10.1111/j.2517-6161.1995.tb02031.x

Berkes, F. 1999. Sacred ecology: traditional ecological knowledge and resource management. Taylor and Francis, Philadelphia, Pensylvania, USA.

Bernard, F. E. 1972. East of Mount Kenya: Meru agriculture in transition. Weltforum Verlag, München, Germany.

Bosselman, F. 2005. Adaptive resource management through customary law. Pages 245-281 in P. Ørebech, F. Bosselman, J. Bjarup, D. Callies, M. Chanock, and H. Petersen, editors. The role of customary law in sustainable development. Cambridge University Press, Cambridge, UK. https://doi.org/10.1017/ CBO9780511550621.008

Braithwaite, J. 2002. Rules and principles: a theory of legal certainty. Australian Journal of Legal Philosophy 27:47-82. http:// dx.doi.org/10.2139/ssrn.329400

Carrier, N. C. M. 2007. Kenyan khat: the social life of a stimulant. Brill, Leiden, Netherlands. https://doi.org/10.1163/ej.9789004156593. $\underline{\mathrm{i}-288}$

Carrier, N., and G. Klantschnig. 2018. Quasilegality: khat, cannabis and Africa's drug laws. Third World Quarterly 39 (2):350-365. https://doi.org/10.1080/01436597.2017.1368383

Cleaver, F. 2002. Reinventing institutions: bricolage and the social embeddedness of natural resource management. European Journal of Development Research 14(2):11-30. https://doi. org/10.1080/714000425

Colding, J., and C. Folke. 2001. Social taboos: "invisible" systems of local resource management and biological conservation. Ecological Applications 11(2):584-600. https://doi.org/10.1890/1051-0761 (2001)011[0584:stisol]2.0.co;2

Cox, M., S. Villamayor-Tomas, and Y. Hartberg. 2014. The role of religion in community-based natural resource management. World Development 54:46-55. https://doi.org/10.1016/j. worlddev.2013.07.010

Dagan, H., and M. A. Heller. 2001. The liberal commons. Yale Law Journal 110(4):549-623. [online] URL: https://repository.law. umich.edu/cgi/viewcontent.cgi?article $=2468 \&$ context $=$ articles

de Bon, H., J. Huat, L. Parrot, A. Sinzogan, T. Martin, E. Malézieux, and J.-F. Vayssières. 2014. Pesticide risks from fruit and vegetable pest management by small farmers in sub-Saharan Africa. A review. Agronomy for Sustainable Development 34 (4):723-736. https://doi.org/10.1007/s13593-014-0216-7

De Herdt, T., and J.-P. Olivier de Sardan. 2015. Real governance and practical norms in sub-Saharan Africa. Routledge, London, UK. https://doi.org/10.4324/9781315723365 
European Environment Agency (EEA). 2018. Environmental indicator report 2018, briefings, priority objective 3: to safeguard the Union's citizens from environment-related pressures and risks to health and well-being, pesticide sales. European Environment Agency, Copenhagen, Denmark. [online] URL: https://www.eea. europa.eu/airs/2018/environment-and-health/pesticides-sales

Eisenberg, A. 2019. Pluralism and the authority of groups to discriminate. Critical Review of International Social and Political Philosophy. https://doi.org/10.1080/13698230.2019.1610844

Ellickson, R. C. 1991. Order without law: how neighbors settle disputes. Harvard University Press, Cambridge, Massachusetts, USA. https://doi.org/10.2307/j.ctvk12rdz

Fabinyi, M., L. Evans, and S. J. Foale. 2014. Social-ecological systems, social diversity, and power: insights from anthropology and political ecology. Ecology and Society 19(4):28. https://doi. org/10.5751/ES-07029-190428

Fadiman, J. A. 1977. Mountain witchcraft: supernatural practices and practitioners among the Meru of Mount Kenya. African Studies Review 20(1):87-101. https://doi.org/10.2307/523864

Fadiman, J. A. 1993. When we began, there were witchmen: an oral history from Mount Kenya. University of California Press, Berkeley, USA. https://doi.org/10.1086/ahr/100.2.563

Goldsmith, P. 1994. Symbiosis and transformation in Kenya's Meru district. Dissertation. University of Florida, Gainesville, Florida, USA. [online] URL: https://ufdc.ufl.edu/AA00025717/00001/1j

Goulson, D. 2019. The insect apocalypse, and why it matters. Current Biology Magazine 29:R942-R995. https://doi.org/10.1016/ j.cub.2019.06.069

Harrison, J. L. 2020. Pesticide purveyors and corporate power. Pages 51-62 in S. Jayaraman and K. De Master, editors. Bite back: people taking on corporate food and winning. University of California Press, Oakland, USA. https://doi.org/10.2307/j. ctvwcjhvs.7

Helbling, J., W. Kälin, and P. Nobirabo. 2015. Access to justice, impunity and legal pluralism in Kenya. Journal of Legal Pluralism and Unofficial Law 47(2):347-367. https://doi.org/10.1080/07329113.2015.1080430

Hendriks, C. M. J., H. S. Gibson, A. Trett, A. Python, D. J. Weiss, A. Vrieling, M. Coleman, P. W. Gething, P. A. Hancock, and C. L. Moyes. 2019. Mapping geospatial processes affecting the environmental fate of agricultural pesticides in Africa. International Journal of Environmental Research and Public Health 16(19):3523. https://doi.org/10.3390/ijerph16193523

Humphrey, J. 2008. Private standards, small farmers and donor policy: EUREPGAP in Kenya. IDS Working Paper 308. Institute of Development Studies, Brighton, UK. [online] URL: https:// opendocs.ids.ac.uk/opendocs/handle/20.500.12413/4167

Ishida, S. 2007. Contemporary agriculture in Nyambene District. Pages 41-66 in N. Gîchere and S. Ishida, editors. The indigenous knowledge of the Ameru of Kenya. Meru Museum, Meru, Kenya.

Jansen, K. 2007. The unspeakable ban: the translation of global pesticide governance into Honduran national regulation. World Development 36:575-589. https://doi.org/10.1016/j.worlddev.2007.04.017
Karp, D. S., P. Baur, E. R. Atwill, K. De Master, S. Gennet, A. Iles, J. L. Nelson, A. R. Sciligo, and C. Kremen. 2015. The unintended ecological and social impacts of food safety regulations in California's central coast region. BioScience 65 (12):1173-1183. https://doi.org/10.1093/biosci/biv152

Karp, D. S., R. Moses, S. Gennet, M. S. Jones, S. Joseph, L. K. M'Gonigle, L. C. Ponisio, W. E. Snyder, and C. Kremen. 2016. Agricultural practices for food safety threaten pest control services for fresh produce. Journal of Applied Ecology 53:1402-1412. https://doi.org/10.1111/1365-2664.12707

Kenya National Bureau of Statistics (KNBS). 2019. 2019 Kenya population and housing census: volume I. Kenya National Bureau of Statistics, Nairobi, Kenya. [online] URL: https://www.knbs.or. ke/?wpdmpro=2019-kenya-population-and-housing-census-volumei-population-by-county-and-sub-county

Keyd, H. M., and L. Buur. 2007. Traditional authority and democratization in Africa. Pages 1-30 in L. Buur and H. M. Keyd, editors. State recognition and democratization in sub-Saharan Africa: a new dawn for traditional authorities? Palgrave Macmillan, London, UK. https://doi.org/10.1057/9780230609716_1

Knudsen, S. H. 2017. Regulating cumulative risk. Minnesota Law Review 101:2313-2396. [online] URL: https://www.minnesotalawreview. org/wp-content/uploads/2017/06/Knudsen.pdf

Krueger, J. 2016. Autonomy and morality: legal pluralism factors impacting sustainable natural resource management among miraa farmers in Nyambene Hills, Kenya. Journal of Legal Pluralism and Unofficial Law 48(3):415-440. https://doi. org/10.1080/07329113.2016.1239318

Krueger, J., and H. Jacobs. 2016. Responsible localism, reactionary localism: lessons on land use controls and sustainability from the global south for the global north. Public Sector 42(1):121-129. [online] URL: https://www.harveymjacobs. com/wp-content/uploads/2018/06/Krueger-and-Jacobs-2016-ResponsibleLocalism-PublicSector.pdf

Levins, R. A., and W. W. Cochrane. 1996. The treadmill revisited. Land Economics 72(4):550-553. https://doi.org/10.2307/3146915

Luna, J. K. 2020. 'Pesticides are our children now': cultural change and the technological treadmill in the Burkina Faso cotton sector. Agriculture and Human Values 37:449-462. https://doi. org/10.1007/s10460-019-09999-y

Lydy, M., J. Belden, C. Wheelock, B. Hammock, and D. Denton. 2004. Challenges in regulating pesticide mixtures. Ecology and Society 9(6):1. https://doi.org/10.5751/ES-00694-090601

Marquez, E. C., and K. S. Schafer. 2016. Kids on the frontline: how pesticides are undermining the health of rural children. Pesticide Action Network North America, Oakland, California, USA. [online] URL: http://www.panna.org/sites/default/files/ KOF-report-final.pdf

Mengistie, B. T., A. P. J. Mol, and P. Oosterveer. 2017. Pesticide use practices among smallholder vegetable farmers in Ethiopian central rift valley. Environment, Development and Sustainability 19:301-324. https://doi.org/10.1007/s10668-015-9728-9

Ngowi, A. V. F., T. J. Mbise, A. S. M. Ijani, L. London, and O. C. Ajayi. 2007. Smallholder vegetable farmers in Northern 
Tanzania: pesticides use practices, perceptions, cost and health effects. Crop Protection 26:1617-1624. https://doi.org/10.1016/j. cropro.2007.01.008

Nicolopoulou-Stamati, P., S. Maipas, C. Kotampasi, P. Stamatis, and L. Hens. 2016. Chemical pesticides and human health: the urgent need for a new concept in agriculture. Frontiers in Public Health 4:148. https://doi.org/10.3389/fpubh.2016.00148

Noe, E. B., and H. F. Alrøe. 2015. Regulation of agroecosystems: a social systems analysis of agroecology and law. Pages 31-45 in M. Monteduro, et al., editors. Law and agroecology: a transdisciplinary ialogue. Springer, New York, New York, USA. https://doi.org/10.1007/978-3-662-46617-9 2

Ochilo, W. N., M. Otipa, M. L. Oronje, F. Chege, E. K. Lingeera, E. Lusenaka, and E. O. Okonjo. 2018. Pest management practices prescribed by frontline extension workers in the smallholder agricultural subsector of Kenya. Journal of Integrated Pest Management 9(1):1-9. https://doi.org/10.1093/jipm/pmy009

Ostrom, E. 1990. Governing the commons: the evolution of institutions for collective action. Cambridge University Press, Cambridge, UK.

Ottiger, F., B. Kiteme, and J. Jacobi. 2020. Highly hazardous pesticides (HHPs) in agro-industrial and smallholder farming systems in Kenya. CDE Policy Brief. Centre for Development and Environment, University of Bern, Bern, Switzerland. https://doi. org/10.46446/publication r4d.2020.3.en

Ouma, S. 2010. Global standards, local realities: private agrifood governance and restructuring of the Kenyan horticulture industry. Economic Geography 86(2):197-222. https://doi. org/10.1111/j.1944-8287.2009.01065.X

Pollans, M. J. 2015. Regulating farming: balancing food safety and environmental protection in a cooperative governance regime. Wake Forest Law Review 50:399-460. [online] URL: https://digitalcommons.pace.edu/lawfaculty/1003/

Pretty, J., and Z. P. Bharucha. 2015. Integrated pest management for sustainable intensification of agriculture in Asia and Africa. Insects 6:152-182. https://doi.org/10.3390/insects6010152

R Development Core Team. 2017. R: a language and environment for statistical computing. R Foundation for Statistical Computing, Vienna, Austria. [online] URL: http://www.R-project.org/

Sage, C., and M. Woolcock. 2012. Introduction: legal pluralism and development policy - scholars and practitioners in dialogue. Pages 1-18 in B. Z. Tamanaha, C. Sage, and M. Woolcock, editors. Legal pluralism and development: scholars and practitioners in dialogue. Cambridge University Press, Cambridge, UK. https:// doi.org/10.1017/cbo9781139094597.002

Sagy, T. 2011. What's so private about private ordering? Law and Society Review 45(4):923-954. https://doi.org/10.1111/ j.1540-5893.2011.00461.x

Sheahan, M., and C. B. Barrett. 2017. Ten striking facts about agricultural input use in sub-Saharan Africa. Food Policy 67:12-25. https://doi.org/10.1016/j.foodpol.2016.09.010

Silva, V., H. G. J. Mol, P. Zomer, M. Tienstra, C. J. Ritsema, and V. Geissen. 2019. Pesticide residues in European agricultural soils
- a hidden reality unfolded. Science of the Total Environment 653:1532-1545. https://doi.org/10.1016/j.scitotenv.2018.10.441

Tallontire, A., M. Opondo, and V. Nelson. 2014. Contingent spaces for smallholder participation in GlobalGAP: insights from Kenyan horticulture value chains. Geographical Journal 180 (4):353-364. https://doi.org/10.1111/geoj.12047

Thomas, L. M. 2003. Politics of the womb: women, reproduction, and the state in Kenya. University of California Press, Berkeley, California, USA. 